\title{
EVIDENCE OF APOPTOSIS \\ IN PARVOCELLULAR NUCLEI OF HYPOTHALAMUS IN STREPTOZOTOZIN-INDUCED DIABETES MELLITUS ${ }^{*}$
}

\author{
O. Ya. Zhurakivska ${ }^{1}$, N. M. Zherdova ${ }^{2}$, R. P. Oliynyk ${ }^{1}$, N. G. Pobigun ${ }^{1}$, \\ I. O. Kostitska ${ }^{1}$, V. M. Zhurakivskyi ${ }^{1}$, V. A. Miskivi, Yu. L. Tkachuk ${ }^{1}$, \\ O. V. Antymys ${ }^{1}$, N. T. Sahan ${ }^{1}$, T. V. Kniazevych-Chorna ${ }^{1}$ \\ ${ }^{1}$ Ivano-Frankivsk National Medical University, Ivano-Frankivsk, Ukraine \\ ${ }^{2}$ Center for Innovation Medical Technology of the National Academy of Sciences of Ukraine, \\ Kyiv, Ukraine \\ zhurakivska.o.ya@gmail.com
}

Diabetes mellitus (DM) causes great socio-economic damage, which is determined by medical expenses and expenditure on social security to patients due to invalidity and loss of labour capacity [1, 2]. More than 1 million patients with DM are registered in Ukraine, but the actual number of people with undiagnosed pathology exceeds this figure by 3-4 times [3].

In search of new effective methods of treatment and prevention of this disease, researchers have recently focused on studying the role of hypothalamic neuropeptides and their participation in the regulation of pancreatic islet function $[4,5,6]$.

Thus, neurohormones of the middle region of the hypothalamus, in particular the arcuate nucleus (AN), affect exo- and endocrine functions of the pancreas. Irritation of AN causes the release of insulin by B cells [4, 5]; the electrical stimulation of the ventromedial nucleus (VN) leads to changes in blood glucose levels [6].

A number of researchers have identified two types of neurons in the hypothalamic VN: glucose-excited and glucose-inhibited which respond to blood sugar levels, thereby stimulating food intake in hypoglycemia or insulin secretion in hyperglycemia [7, 8]. The same authors argue that the glucose-excited and glucose-inhibited neurons of VN are part of the ultimate safety that protects the brain from acute glucose deficiency. They proved that metabolic disorders in these cells lead to their hypersensitivity, so even small fluctuations in

* The dissertation research was performed according to the plan of Ivano-Frankivsk National Medical University and is a fragment of two research works of the Department of Human Anatomy: «Optimization of complex treatment of morphological disorders of the digestive, endocrine and urogenital systems in diabetes mellitus» (state registration number 0113U000769), "Age features of pathomorphogenesis of some organs of the neuroendocrine, cardiovascular, digestive and respiratory systems in diabetes mellitus» (state registration number 0116U003598), which were funded by the Ministry of Health of Ukraine.

The authors assume responsibility for the published work.

The authors guarantee the absence of competing interests and their financial interest when carrying out the research and writing the article.

The manuscript was received by the editorial staff 18.08.2021. 
blood glucose levels cause hyperphagia, obesity and the development of type 2 diabetes.

In view of the above, the aim of our study was to establish the features of morphofunc- tional changes in $\mathrm{AN}$ and $\mathrm{VN}$ of the hypothalamus in streptozotocin-induced diabetes mellitus (SIDM).

\section{MATERIAL AND METHODS}

The study used 20 white male Wistar rats 12 months of age (weighing 200-220 g), which were equally divided into two groups: control and experimental ones with induced SIDM. Induction of SIDM was performed by a single intraperitoneal injection of streptozotocin «SIGMA» (USA), which was diluted in $0.1 \mathrm{M}$ citrate buffer with a $\mathrm{pH}$ of 4.5 , at a dose of $6 \mathrm{mg}$ per $100 \mathrm{~g}$ of body mass. The experimental model of SIDM is close to human type 1 diabetes mellitus. In an equivalent dose $0.1 \mathrm{M}$ citrate buffer with a $\mathrm{pH}$ of 4.5 was injected intraperitoneally to animals in the control subgroup. All manipulations performed on animals during the experiment did not violate ethical standards in accordance with the provisions of the European Convention for the protection of vertebrate animals used for research and other scientific purposes (Strasbourg, 1986), Council Directive 86/609/EEC (1986), Law of Ukraine "On protection of animals from cruel treatment» of December 15, 2009 and orders of the Ministry of Health of Ukraine No. 690 of 23.09.2009, No. 616 of 03.08.2012 and met the requirements of the Ethics Commission of Ivano-Frankivsk National Medical University. The material was taken on the $14^{\text {th }}$ and $70^{\text {th }}$ days from the beginning of the induction of SIDM.

In the histological examination, paraffin sections with a thickness of 5.0-7.0 $\mu \mathrm{m}$ were stained by the method of Nissl. The TUNEL method and the Apop Tag Plus Peroxidase In Situ Apoptosis Detection Kit (manufactured by Milliporen, USA) were used to detect apoptotic cells in the hypothalamus.

For qualitative electron microscopic examination, a part of the material was pre-fixed in $2.5 \%$ glutaraldehyde solution, followed by fixation in $2 \%$ osmium tetroxide solution; it was performed and contrasted according to the conventional method. The study of the material was performed on an electron microscope PEM$125 \mathrm{~K}$. For preliminary topographic detection of various nuclei of the hypothalamus, semi- thin sections with a thickness of $1 \mu \mathrm{m}$ were stained with $1 \%$ methylene blue solution.

Histological specimens and semi-thin sections were examined under a light microscope MC 300 (TXP), Leika DME and photographed using a Digital camera for microscope DCM 900 and a Nicon Coolpix P5100.

For morphometric studies, photographs of histological and semi-thin sections saved in TIF format were used. The numerical density of neurons (NDN), gliocytes (NDG) and capillaries (NDC) in AN and VN was calculated on the test area of $0.01 \mathrm{~mm}^{2}$ [9]. The glial index (GI) (the ratio of the numerical density of gliocytes and neurons) was determined. The number of apoptotic nuclei of NCs on the area of $0.5 \mathrm{~mm}^{2}$ of the studied nuclei was counted. The apoptotic index was determined, which characterizes the number of apoptotic nuclei per 100 studied cells, followed by a percentage calculation.

To measure metric characteristics of neurons, the software NIH USA «Image J» (USA) and "Bio Vision 4.1» (Austria) were used in manual mode, given the magnification. Indicators of the area of the profile field of perikaryons of neuroendocrine cells (NC) and their nuclei, the shape coefficient of the studied nuclei, nuclear-cytoplasmic ratio (NCR) (the ratio of the area of the profile field of the nucleus to the area of the profile field of the cytoplasm) were determined.

A universal measuring millimeter grid with an area of $485.55 \mu^{2}$ was used for objective assessment of the morphofunctional activity of the $\mathrm{NC}$ state. Measurements of neurosecretory granules (NG) were performed on encrypted reverse image with a test line length of $1 \mathrm{~mm}$. The bulk density of different types of $\mathrm{NG}$ was calculated by the formula [9]:

$$
\mathrm{V}_{\mathrm{i}}=\left(\mathrm{P}_{\mathrm{i}} / \mathrm{P}_{\mathrm{t}}\right) \times 100 \% \text {, }
$$

where $\mathrm{V}_{\mathrm{i}}$ is the bulk density of the test object, $P_{i}$ is the number of dots inside the test object, $\mathrm{P}_{t}$ is the total number of dots of the test system.

Glucose level was determined by glucose oxidase method and daily measurement using 
test strips on a glucometer "Accu Chec» (Germany) from a drop of tail vein blood. The biochemical markers of diabetes (insulin and glycosylated hemoglobin (HbA1c) were determined in a certified laboratory "Diameb».

Computer data processing was performed using the statistical package Stat. Soft. Inc; Tulsa, OK, USA; Statistica 6. Nonparametric research methods (Wilcoxon and Mann-Whitney tests) were used. For the analysis of quali- tative features (share, percentage), the analysis of conjugation tables was applied: Chi-square $\left(\mathrm{X}^{2}\right)$. Statistical changes were considered significant when the achieved level of statistical significance was $p<0.05$. Indicators, values, parameters both in the text and in the tables are presented as follows: $\mathrm{M}$ - sample mean, $\mathrm{m}$ standard error of the mean, $\mathrm{p}$ - the achieved level of statistical probability.

\section{RESULTS AND THEIR DISCUSSION}

On the $14^{\text {th }}$ day of SIDM development, the level of glucose and $\mathrm{HbA1c}$ increases up to $13.57 \pm 0.36 \mathrm{mmol} / \mathrm{l}($ control $-5.29 \pm 0.18 \mathrm{mmol} / \mathrm{l}$, $\mathrm{p}<0.01$ ) and $6.78 \pm 0.18 \%$ (control $-2.23 \pm$ $0.08 \%, \mathrm{p}<0.001)$, respectively, against the background of reducing insulin up to $1.41 \pm$
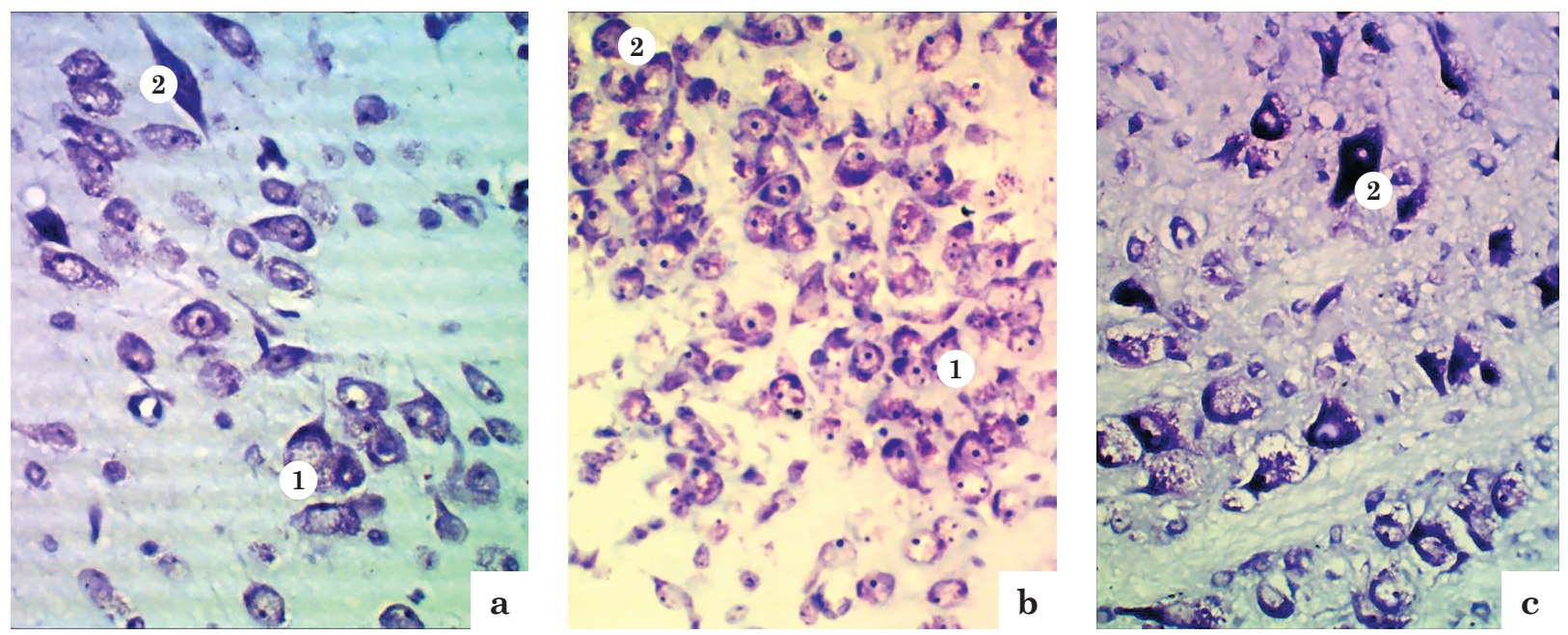

Fig. 1. Impaired distribution of Nissl substance in perikaryons and increase in the number of nucleoli in $\mathrm{NC}$ of $\mathrm{AN}$ on the $14^{\text {th }}$ day of SIDM (b) and apparent chromatolysis in NC of VN

on the $70^{\text {th }}$ day of SIDM (c) compared with $\mathrm{NC}$ of $\mathrm{VN}$ in control rats (a).

Nissl staining. Magn.: a, c) $\times 1000$, b) $\times 400$. Symbols: 1 - light neuron, 2 - dark neuron.
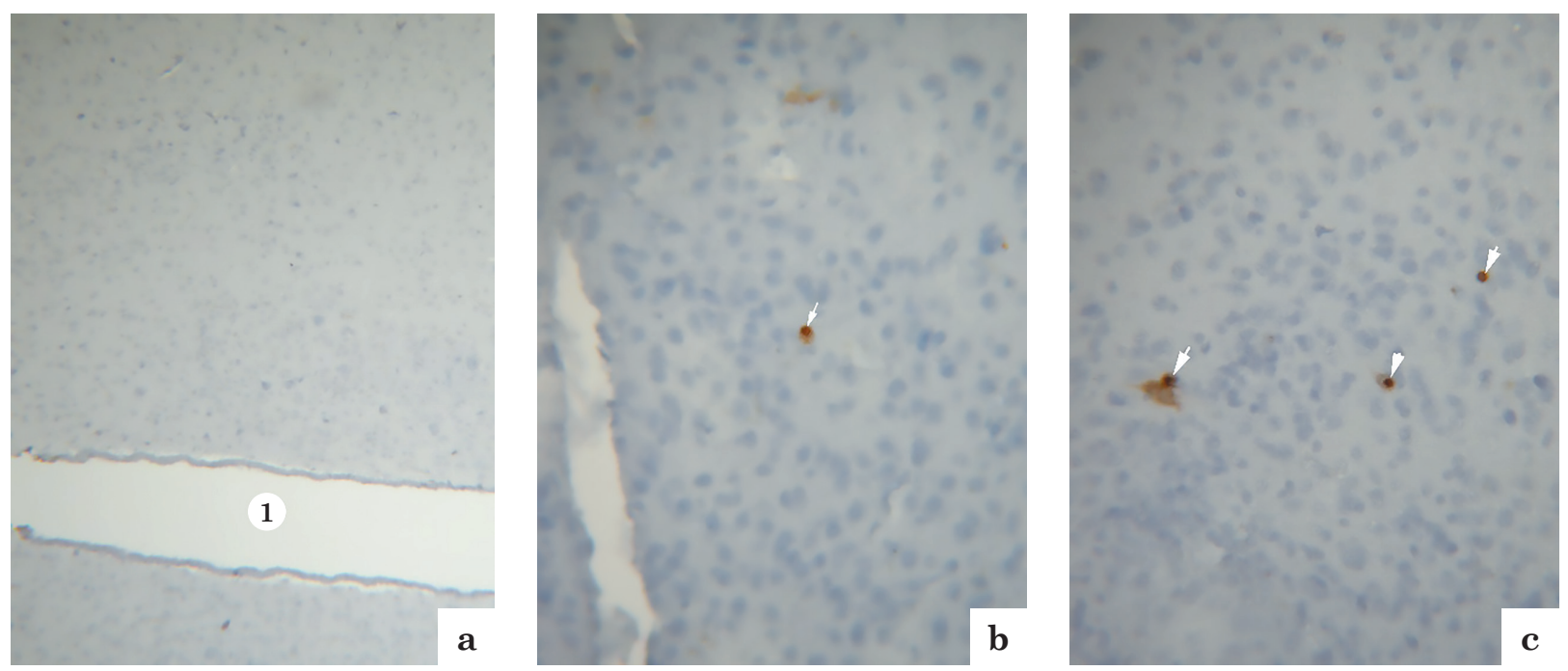

Fig. 2. Structure of VN in the control group (a) and on the $14^{\text {th }}(\mathrm{b})$ and $70^{\text {th }}$ (c) days of the development of SIDM (apoptotic neurons are indicated by an arrow).

NUNEL-marking method. Magn.: a) $\times 100, b, c) \times 400$. Symbols: 1 - cavity of the $3^{\text {rd }}$ ventricle. 
Quantitative parameters of the structure of AN and VN of the hypothalamus of rats with SIDM

\begin{tabular}{|c|c|c|c|c|c|c|c|c|}
\hline & \multirow[b]{2}{*}{ NDN } & \multicolumn{3}{|c|}{ NDN } & \multirow[b]{2}{*}{ NDG } & \multirow[b]{2}{*}{ NDC } & \multirow[b]{2}{*}{ GI } \\
\hline & & & light & dark & $\begin{array}{l}\text { vacuo- } \\
\text { lated }\end{array}$ & & & \\
\hline \multicolumn{9}{|c|}{$14^{\text {th }} \mathrm{day}$} \\
\hline \multirow{2}{*}{$\mathrm{AN}$} & SIDM & $14.2 \pm 2.39$ & $11.3 \pm 0.43^{*}$ & $2.3 \pm 0.13^{*}$ & $2.9 \pm 0.17$ & $11.8 \pm 0.27$ & $1.6 \pm 0.24$ & $0.78 \pm 0.02$ \\
\hline & contol & $15.4 \pm 0.38$ & $14.1 \pm 0.32$ & $1.3 \pm 0.21$ & $2.7 \pm 0.15$ & $11.6 \pm 0.34$ & $1.7 \pm 0.25$ & $0.75 \pm 0.03$ \\
\hline \multirow{2}{*}{$\mathrm{VN}$} & SIDM & $14.3 \pm 0.43$ & $12.4 \pm 0.37 *$ & $1.9 \pm 0.18^{*}$ & $3.7 \pm 0.24^{*}$ & $11.7 \pm 0.29$ & $1.6 \pm 0.27$ & $0.76 \pm 0.02$ \\
\hline & control & $15.6 \pm 0.29$ & $14.3 \pm 0.25$ & $1.3 \pm 0.17$ & $2.6 \pm 0.18$ & $11.4 \pm 0.26$ & $1.5 \pm 0.13$ & $0.73 \pm 0.02$ \\
\hline \multicolumn{9}{|c|}{$70^{\text {th }} \mathrm{day}$} \\
\hline \multirow{2}{*}{$\mathrm{AN}$} & SIDM & $9.2 \pm 0.24^{*, \#}$ & $6.6 \pm 0.29^{*, \#}$ & $2.6 \pm 0.31^{*}$ & $6.9 \pm 0.17$ & $13.7 \pm 0.18$ & $1.2 \pm 0.18$ & $1.49 \pm 0.09^{*, \#}$ \\
\hline & control & $15.3 \pm 0.39$ & $14.1 \pm 0.19$ & $1.2 \pm 0.17$ & $1.9 \pm 0.11$ & $10.2 \pm 0.21$ & $1.5 \pm 0.21$ & $0.67 \pm 0.06$ \\
\hline \multirow{2}{*}{$\mathrm{VN}$} & SIDM & $8.5 \pm 0.49^{*, \#}$ & $5.8 \pm 0.24^{*, \#}$ & $2.5 \pm 0.18$ & $7.3 \pm 0.18^{*, \#}$ & $13.9 \pm 0.21$ & $1.2 \pm 0.24^{*}$ & $1.67 \pm 0.7^{*, \#}$ \\
\hline & control & $15.6 \pm 0.29$ & $14.5 \pm 0.27$ & $1.1 \pm 0.12$ & $1.8 \pm 0.14$ & $11.3 \pm 0.39$ & $1.6 \pm 0.17$ & $0.72 \pm 0.05$ \\
\hline
\end{tabular}

Notes:

1) probable difference compared to the control, ${ }^{*} \mathrm{p}<0.05$;

2) probable difference compared to the previous term of the experiment, ${ }^{\#} \mathrm{p}<0,05$.

$0.07 \mathrm{IU} / \mathrm{ml}$ (control $-3.91 \pm 0.14 \mathrm{IU} / \mathrm{ml}$, $\mathrm{p}<0.001)$. Such biochemical changes are the evidence of the development of a stable form of diabetes.

On the $14^{\text {th }}$ day of SIDM, the enlarged nuclei are displaced to the periphery of the perikaryon and become lighter. The tigroid grains are unevenly distributed in the neuroplasm of $\mathrm{NC}$ bodies. They form clusters on the periphery of the perikaryon, while around the nuclei, where chromatolysis is observed, many binuclear neurons appear (Fig. 1 b).

In $\mathrm{AN}$ and $\mathrm{VN}$ the number of dark and vacuolated NCs increases against decrease in light NCs (Table 1). There is an increase in the area of the nuclei of $\mathrm{NC}$ in $\mathrm{AN}$ and their NCR (Table 2).

Using the method of TUNEL-marking, it was found that on the $14^{\text {th }}$ day of the development of SIDM there was no significant difference between the number of apoptotic NCs in $\mathrm{AN}$ and $\mathrm{VN}$ of sick and control animals (Fig. $2 \mathrm{a}-\mathrm{b}$ ). The number of apoptotic NCs in $\mathrm{VN}$ is $0.71 \pm 0.18$ (control $-0.85 \pm 0.14$, $\mathrm{p}>0.05$ ), in $\mathrm{AN}-0.86 \pm 0.14$ (control $0.71 \pm 0.18, p>0.05)$. The apoptosis index in the studied nuclei ranged from $0-1 \%$.

Light NCs in AN of animals are in the phase of hypersecretion. Their enlarged nu- clei contain two nucleoli with high electronoptical density, and the perinuclear space is expanded. Near the nucleus, there is a hypertrophied Golgi complex (Fig. 3 a) and a small amount of NGs. The latter accumulate in the processes of neurons. The bulk density of NG, compared with the control, increases up to $0.68 \pm 0.03 \%$ (control $-0.34 \pm 0.02 \%, p<0.01$ ). Mitochondria increase in volume, their matrix becomes lighter, and cristae are partially destroyed and disorganized.

Karyorexis is noted in dark NC of AN. Karyolema forms deep invaginations, the perinuclear space is well visualized. Cisterns of granular endoplasmic reticulum (GER) are expanded and fill the whole cytoplasm of the perikaryon (Fig. 3 b). In the neuroplasm, there is a large number of lysosomes and NGs, which sometimes merge with each other (Fig. 3 b). Like in light NCs, the bulk density of NG increases to $2.34 \pm 0.12 \%$ (control $1.89 \pm 0.13 \%, \mathrm{p}<0.05)$.

Destructive changes of mitochondria are noted in the majority of light NCs of VN. Some of them have a light matrix, in others the destruction of the inner shell leads to the formation of vacuoles. The protein-synthesizing apparatus is represented by separate ribosomes and polysomes. The number of GER cisterns is 
Morphometric parameters of NC in AN and VN in SIDM

\begin{tabular}{|c|c|c|c|c|c|}
\hline & & $\begin{array}{c}\text { Nucleus area } \\
\left(\mu \mathrm{m}^{2}\right)\end{array}$ & $\begin{array}{l}\text { Shape factor of } \\
\text { the nucleus }\end{array}$ & $\begin{array}{c}\text { Cell area } \\
\left(\mu \mathrm{m}^{2}\right)\end{array}$ & NCR \\
\hline \multicolumn{6}{|c|}{$14^{\text {th }} d a y$} \\
\hline \multirow{2}{*}{$\mathrm{AN}$} & experiment & $87.78 \pm 1.91^{*}$ & $0.71 \pm 0.02$ & $222.29 \pm 1.57$ & $0.65 \pm 0.08^{*}$ \\
\hline & control & $70.65 \pm 2.46$ & $0.72 \pm 0.01$ & $218.34 \pm 6.54$ & $0.48 \pm 0.09$ \\
\hline \multirow{2}{*}{$\mathrm{VN}$} & experiment & $76.53 \pm 1.39$ & $0.71 \pm 0.01$ & $200.95 \pm 5.98$ & $0.61 \pm 0.03$ \\
\hline & control & $78.54 \pm 2.05$ & $0.73 \pm 0.02$ & $194.83 \pm 6.36$ & $0.67 \pm 0.05$ \\
\hline \multicolumn{6}{|c|}{$70^{\text {th }} \mathrm{day}$} \\
\hline \multirow{2}{*}{$\mathrm{AN}$} & experiment & $60.01 \pm 1.54^{* \#}$ & $0.86 \pm 0.03^{* \#}$ & $268.425 .59^{* \#}$ & $0.29 \pm 0.07^{* \#}$ \\
\hline & control & $71.36 \pm 1.89$ & $0.72 \pm 0.02$ & $219.65 \pm 1.73$ & $0.48 \pm 0.02$ \\
\hline \multirow{2}{*}{$\mathrm{VN}$} & experiment & $49.05 \pm 1.42^{* \#}$ & $0.83 \pm 0.02^{* \#}$ & $248.21 \pm 3.63^{* \#}$ & $0.25 \pm 0.03^{* \#}$ \\
\hline & control & $75.39 \pm 2.18$ & $0.71 \pm 0.03$ & $184.75 \pm 4.29$ & $0.69 \pm 0.04$ \\
\hline
\end{tabular}

Notes:

1) probable difference compared to the control, ${ }^{*} \mathrm{p}<0.05$;

2) probable difference compared to the previous term of the experiment, ${ }^{*} \mathrm{p}<0.05$.

significantly reduced, and the remaining ones are expanded, with single ribosomes attached to their surface. The bulk density of NG significantly increases up to $0.36 \pm 0.02 \%$ (control $0.21 \pm 0.02 \%, \mathrm{p}<0.05)$, while in dark $\mathrm{NC}$ it probably does not change and is $0.89 \pm 0.05 \%$ (control $-0.87 \pm 0.02 \%, \mathrm{p}<0.05$ ).

Thus, in the early stages of SIDM development, the polymorphic changes are observed. In $\mathrm{NC}$ of $\mathrm{AN}$ and $\mathrm{VN}$, the numerical density of dark NCs increases and dinuclear light NCs appear. In light $\mathrm{NC}$ of $\mathrm{AN}$ and $\mathrm{VN}$, there is a significant increase in the bulk density of NGs by 2.8-1.7 times. In the axons of the parvocellular nuclei of the outer zone of the median increase, the bulk density of NGs increases by 48-150 \% [10]. Such morphofunctional changes in the parvocellular nuclei of the hypothalamus and changes in the bulk density of NGs in the outer zone of the median increase indicate boosted synthesis of neurohormones which directly affect the adenohypophysis. Other researchers noted an increase in corticoliberin levels in the blood in the fourth week of streptozotocin diabetes [11]; and immunohistochemical methods proved that the neurons of AN and VN are most involved [12]. The development of a stress response, manifested by increased functional activity of adenohypophysis corticotropes, which coincided with the functional stress of cells of zona fasciculata and was accompanied by an increase in peripheral blood cortisol in diabetes, has been described by other researchers [13]. The researchers believe that adrenocorticotropic hormone (ACTH) stimulates $\mathrm{Ca}^{2+}$-dependent processes of insulin secretion and activation of protein through its receptors on the $\mathrm{B}$ cells of the pancreatic islets. $\mathrm{AN}$ of the hypothalamus and endocrinocytes of the pancreatic islets secrete ACTH 22-395 or insulotropin, which causes an increase in insulin secretion by B cells [14]. This hormone plays an important role in stressful situattions, providing the neurons of the brain with glucose. A significant direct correlation between the area of the nuclei of $\mathrm{NC}$ of $\mathrm{AN}$ and the level of insulin in the blood was also found by us. Some researchers [14] have proved that ACTH 22-395 may be involved in feedback mechanisms due to the insulin, and its impaired secretion by the pituitary gland may be a central factor in obesity, insulin resistance, and type 2 diabetes. Most researchers are inclined to believe that in the early stages of DM the level of somatoliberin increases [15] which, in turn, promotes the growth of somatotropic hormone. The latter stimulates the secretion of insulin and glucagon by the pancreatic islets, while activating liver insulinase and reducing tissue sensitivity to insulin. Today, $12-20 \%$ of patients with acromegaly are diagnosed with pituitary diabetes, and in other cases the development of 
insulin resistance is noted [16]. In vitro experiments have shown that on isolated fetal pancreatic islets incubated with somatotropic hormone, glucose metabolism, insulin release, and DNA replication in B cells depend on its effects [17].

On the $70^{\text {th }}$ day of SIDM, the level of glucose and HbA1c continues to increase up to $18.08 \pm 0.21 \mathrm{mmol} / \mathrm{l}$ (control $-5.06 \pm 0.18$ $\mathrm{mmol} / \mathrm{l}, \mathrm{p}<0.01$ ) and $10.82 \pm 0.21 \%$ (control $2.34 \pm 0.18 \%, \mathrm{p}<0.001)$, respectively, against the background of reducing insulin up to $0.76 \pm 0.03 \mathrm{U} / \mathrm{ml}$ (control $-4.02 \pm 0.14 \mathrm{IU} / \mathrm{ml}$, $\mathrm{p}<0.001$ ), which indicates the development of decompensated diabetes.

On the $70^{\text {th }}$ day of the course of SIDM in $\mathrm{AN}$ and $\mathrm{VN}$ the expressed chromatolysis of Nissl substance of NCs is noted, their contours become indistinct (Fig. $1 \mathrm{c}$ ). The nuclei are hypochromic, with significant invaginations of the cariolema and a dark nucleolus. Some perikaryons are shrunken, pycnomorphic, and there is a proliferation of mantle gliocytes around them. Along with this, there are neurons with irreversible destructive changes, which lead to the formation of shadow cells. Morphometric analysis of quantitative composition of the studied nuclei of the hypothalamus indicates a further decrease in NDN, compared with the previous term of the experiment and the control due to light NCs (Table 1), while the number of vacuolated NCs, NDG and GI increases. Cytokaryometric analysis of $\mathrm{NC}$ of rats, compared with the previous term of the experiment, indicates a further increase in the area of the perikaryon against the background of a decrease in the nuclei of neurons, which leads to a decrease in NCR (Table 2). Shape factor of nuclei significantly increases compared with the previous term of the experiment and does not differ from the control indicators, which indicates edema in the nuclei.

The number of apoptotic NCs in AN and $\mathrm{VN}$ increases up to $2.86 \pm 0.26$ (control $0.86 \pm 0.13, \mathrm{p}<0.05$ ) and $3.43 \pm 0.21$ (control $0.83 \pm 0.17, \mathrm{p}<0.05$ ), respectively (Fig. 2 c). Apoptotic index ranges from 2-4\% (control 0-1\%).

At the ultrastructural level, the destructive processes in $\mathrm{NC}$ of $\mathrm{AN}$ and $\mathrm{VN}$ increase. There are light NCs with partial necrosis (Fig. 4 a). The neuroplasm of such cells is occupied by large cisterns - vacuoles, and membrane organelles are not detected. In dark $\mathrm{NCs}$, there are karyopyknosis, karyolysis and ruptures of a plasmolemma (Fig. 4 b). Cisterns of GER are expanded and partially destroyed. Autophagosomes, lipofuscin granules, small and large vacuoles are found in the neuroplasm. Such neurons are surrounded by microand macroglial cells (Fig. 4 c), which contain a large number of lysosomes, autophagosomes
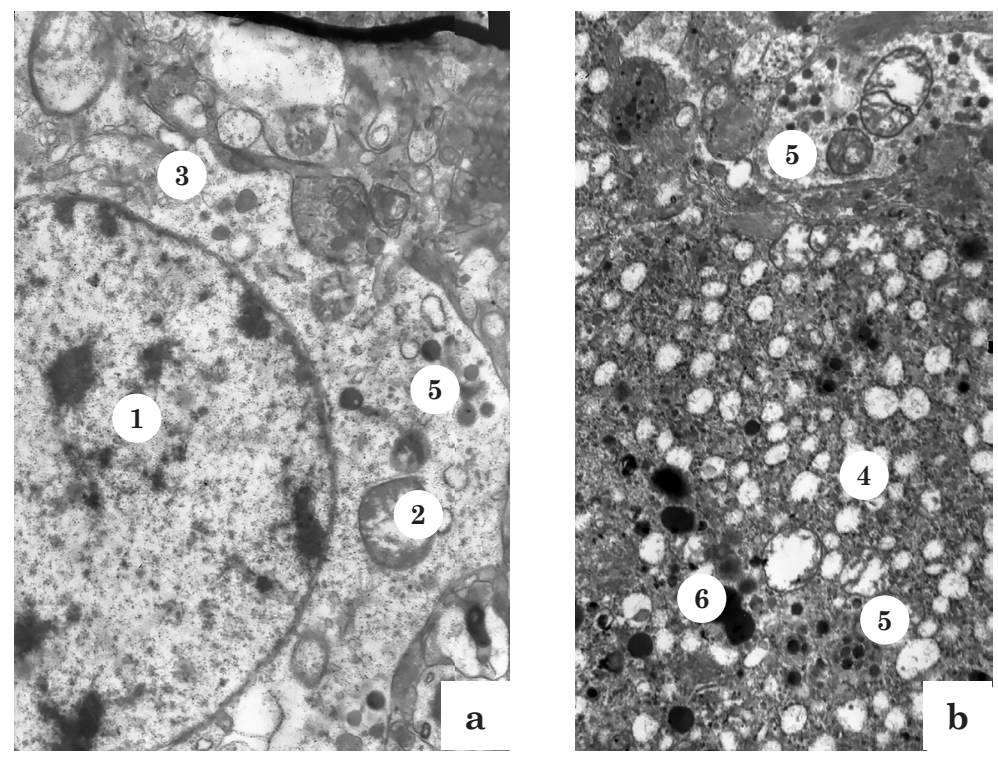

Fig. 3. Ultrastructural changes of light (a) and dark (b) NC in AN of the hypothalamus on the $14^{\text {th }}$ day of SIDM development. Electronic microphotographs.

Magn.: a, b) $\times 8000$. Symbols: 1 - neuron nucleus, $2-$ mitochondria, 3 - Golgi complex, 4 - granular endoplasmic reticulum, 5 - neurosecretory granules, 6 - lysosomes. 

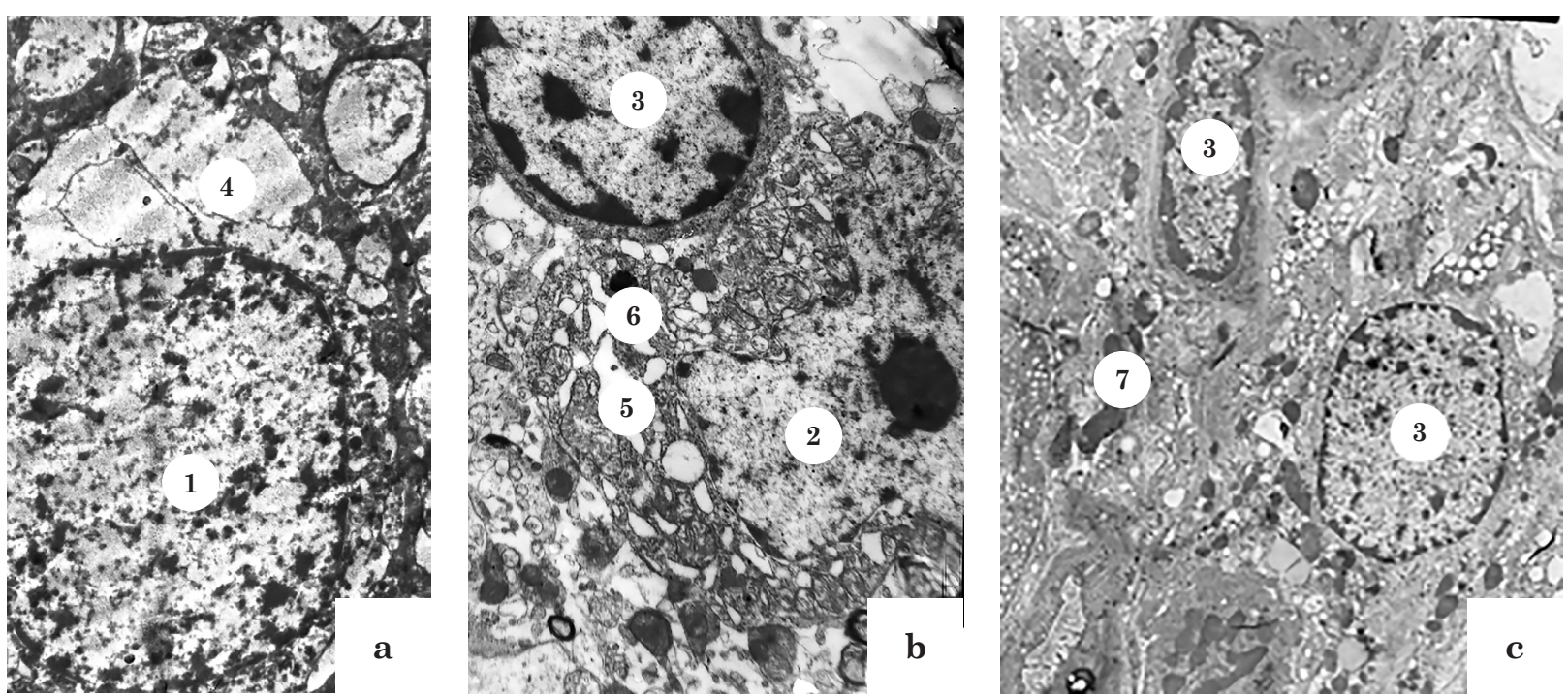

Fig. 4. Submicroscopic changes in VN of the hypothalamus on the $70^{\text {th }}$ day of SIDM. Magn.: a, b) 6400, c) 4000

1 - nucleus of light NC, 2 - nucleus of dark NC, 3 - nucleus of gliocyte, 4 - vacuoles,

5 - granular endoplasmic reticulum, 6 - lipofuscin granule, 7 - residual bodies.

and residual bodies, indicating the active processes of neuronophagy in the studied nuclei. The bulk density of NG decreases, compared with the previous term of the experiment. In light $\mathrm{NC}$ of $\mathrm{AN}$ and $\mathrm{VN}$ it decreases up to $0.12 \pm 0.03 \%$ (control $-0.23 \pm 0.03 \%, \mathrm{p}<0.01$ ) and $0.08 \pm 0.02 \%$ (control $-0.22 \pm 0.02 \%$, $\mathrm{p}<0.05$ ), respectively; in dark $\mathrm{NC}-$ up to $0.86 \pm 0.14 \%$ (control $-1.83 \pm 0.16 \%, \mathrm{p}<0.05$ ) and $0.18 \pm 0.02 \%$ (control $-0.85 \pm 0.05 \%$, $\mathrm{p}<0.05)$ and is less than the control values (in all cases $\mathrm{p}<0.05$ ).

According to our studies, pronounced destructive processes, such as vacuolar dystrophy and apoptosis, were observed in the long-term course of SIDM in VN and AN neurons. Such morphological changes in $\mathrm{NC}$ of different nuclei of the hypothalamus are probably associated with a violation of their metabolism in diabetes [18]. Thus, other researchers have shown that at low insulin levels there are violations of protein synthesis in neurons of the brain and damage to neurofilaments [19]. This, in turn, leads to diabetic encephalopathy $[19,20]$. In this case, hyperglycemia causes apoptosis or necrosis of neurons by tissue acidosis [21]. Thus, mice with diabetes had ultrastructural damage to neurons of the cerebellum, hippocampus and cerebral cortex, which underlies stress-induced depression [18, 19, 21]. The same changes in the central and peripheral systems are observed in people with diabetes [22, 23].

Besides, there is a decrease in the bulk density of NG in NCs of $\mathrm{VN}$ and $\mathrm{AN}$, which may be an indirect indicator of a decrease in the synthesis of liberins and statins in them. This was proved biochemically by other researchers who observed a decrease in blood levels of gonado-, somato-, prolactoliberin in SIDM. In immature rats, this led to growth retardation and delayed puberty [16, 17, 24].

The studying of changes of hypothalamicpituitary system in experimental diabetes mellitus is promising, which will expand and deepen the knowledge about the pathogenetic mechanisms of neurohumoral processes in the body in this disease and will allow to develop the concept of pathomorphogenesis of diabetic neuroendocrinopathies. This model can serve as a theoretical basis for the development of new pathogenetically reasonable methods of treatment of diabetic neuroendocrinopathies and for the preclinical studying of new antidiabetic drugs and their effectiveness.

\section{CONCLUSIONS}

Prolonged hyperglycemia in SIDM causes neuronal death by apoptosis and necrosis in parvocellular nuclei of the hypothalamus and leads to the development of diabetic neuroendocrinopathy. Thus, there are 2 main stages in the pathomorphogenesis of diabetic neuro- 
endocrinopathies of parvocellular nuclei of the hypothalamus:

- compensatory-adaptive processes (on the $14^{\text {th }}$ day), which is characterized by an increase in the area of the perikaryon of $\mathrm{NC}$, their nuclei and NCR, an increase in the bulk density of NG in them;

- pronounced dystrophic-destructive changes (on the $70^{\text {th }}$ day), which are based on damage to the $\mathrm{NC}$ according to the type of vacuolar dystrophy and apoptosis. Some perikaryons undergo irreversible changes, which culminate in their neuronophagia by gliocytes, which leads to a decrease in the numerical density of NCs on the background of satellitosis (increase in NDG and GI).

\section{REFERENCES}

1. Khan MA, Katta M, Gurunadh VS, et al. Med J Armed Forces India 2017; 73(3): 261-266. https://doi.org/10. 1016/j.mjafi.2017.01.005.

2. Fang F, Wang J, Wang Y-F, Peng Y-D. Eur Rev Med Pharmacol Sci 2018; 22(19): 6456-6462. https://doi.org/ 10.26355/eurrev_201810_16058.

3. Rak SO. Nursing 2019;3: 42-44. https://doi.org/10.11603/ 2411-1597.2019.3.10682.

4. Katharina Timper, Jens C Brüning. Dis Model Mech 2017;10(6): 679-689. https://doi.org/10.1242/dmm.026609.

5. Yue Ma, Ratnasabapathy R, Chioma I-E, et al. Diabetes Obes Metab 2018;20(9): 2246-2254. https://doi. org/10.1111/dom.13359.

6. Flak JN, Goforth PB, Dell'Orco J, et al. J Clin Invest 2020;130(6): 2943-2952. https://doi.org/10.1172/JCI134135.

7. Cotero VE, Zhang BB, Routh VH, Cotero VE. J Neuroendocrinol 2010;22(2): 65-74.

8. Routh VH. Sensors 2010;10(10): 9002-9025.

9. Zhurakivska OYa. Galician Med J 2014;21(2): 32-34.

10. Zhurakivska OYa. Clin Experim Morphol 2013;1: 52-55.

11. Revsin Y, van Wijk D, Saravia FE, et al. Endocrinology 2008;149 (7): 3531-3539.

12. Guven A, Yavuz O, Cam M, et al. Int J Neurosci 2009; 119 (8): 1155-1169.
13. Zhurakivska OY, Zhurakivskyi VM, Miskiv VA, et al. Clin Anat Operative Surg 2019;18(2): 82-88.

14. Beauquis J, Homo-Delarche F, Giroix MH, et al. Exp Neurol 2010;222(1): 125-134.

15. Thounaojam MC, Powell FL, Patel S, et al. Proc Natl Acad Sci USA 2017;114(50): 13248-13253. https://doi. org/10.1073/pnas.1718592114.

16. Iijima N, Takumi K, Sawai N, et al. J Mol Neurosci 2011;43(2): 146-154

17. Ludwiga B, Zieglera ChG, Schallyc AV, et al. PNAS 2010;107(28): 2623-2628.

18. McCall AL. Eur J Pharmacol 2004;490(1-3): 147-158.

19. Juan P, Hern'andez-Fonseca, Rincon J, et al. Experim Diab Res 2009;2009: 1-12.

20. Schur MB, Zhurakivska OY. Morphologia 2019;3(13): 170-176.

21. Sima AA. Acta Diabetol 2010;47(4): 279-293.

22. Roustit M, Loader J, Deusenbery C, et al. J Clin Endocrinol Metab 2016;101(9): 34018.

23. Yang X, Huo F, Liu B, et al. J Mol Neurosci 2017;61(4): 581-589. https://doi.org/10.1007/s12031-017-0899-8.

24. Bédard K, Strecko J, Thériault K, et al. Am J Physiol Endocrinol Metab 2008;294(4): E7440-7451. 


\title{
EVIDENCE OF APOPTOSIS IN PARVOCELLULAR NUCLEI OF HYPOTHALAMUS IN STREPTOZOTOZIN-INDUCED DIABETES MELLITUS
}

\author{
O. Ya. Zhurakivska ${ }^{1}$, N. M. Zherdova ${ }^{2}$, R. P. Oliynyk ${ }^{1}$, N. G. Pobigun ${ }^{1}$, \\ I. O. Kostitska ${ }^{1}$, V. M. Zhurakivskyi ${ }^{1}$, V. A. Miskiv ${ }^{1}$, Yu. L. Tkachuk ${ }^{1}$, \\ O. V. Antymys ${ }^{1}$, N. T. Sahan ${ }^{1}$, T. V. Kniazevych-Chorna ${ }^{1}$ \\ ${ }^{1}$ Ivano-Frankivsk National Medical University, Ivano-Frankivsk, Ukraine \\ ${ }^{2}$ Center for Innovation Medical Technology of the National Academy of Sciences of Ukraine, \\ Kyiv, Ukraine \\ zhurakivska.o.ya@gmail.com
}

Diabetes mellitus causes great socio-economic damage, which is determined by medical expenses and expenditure on social security to patients due to invalidity and loss of labour capacity. Researchers are studying the role of hypothalamic neuropeptides and their involvement in the regulation of pancreatic islet function. In view of the above, the aim of our study was to establish the features of morphofunctional changes in the arcuate nucleus (AN) and ventromedial nucleus (VN) of the hypothalamus in streptozotocin-induced diabetes mellitus (SIDM) in Wistar rats. Histological, immunohistochemical, electron-microscopic, biochemical and statistical research methods were used.

Results. Polymorphic changes were noted in AN and VN at early stages of development of SIDM (on the $14^{\text {th }}$ day). In AN, the area of neurons and their nuclei became larger, the numerical density of dark functionally more active neurons increased, and dinuclear light neuroendocrine cells (NC) appeared. In light and dark NCs of AN, there was a significant increase in the bulk density of neurosecretory granules - by $2-4$ times compared with the control, in VN - by 1.2-2 times. Such morphofunctional changes in parvocellular nuclei of the hypothalamus and the increase in the bulk density of neurosecretory granules in their NCs indicate boosted synthesis of neurohormones which directly affect the adenohypophysis and improving functional activity of NCs in $\mathrm{AN}$ and $\mathrm{VN}$.

On the $70^{\text {th }}$ day of SIDM in AN and VN of the hypothalamus, there was a decrease in the numerical density of neurons due to light NC and increase in the numerical density of vacuolated, dark pycnomorphic and apoptotic neurons. The apoptotic index in the studied nuclei of the hypothalamus increased by 2-4 times compared with the control. The area of the profile field of NC increased and the area of nuclei decreased, which led to the reduced nuclear-cytoplasmic index and indicated a decrease in their functional activity and was confirmed by a decrease in the bulk density of neurosecretory granules in NC by 1.9-2.1 times in AN and by 2.7-4.7 times in VN. At the ultrastructural level, pronounced destructive processes such as vacuolar dystrophy, development of satelliteosis and neuronophagia were observed in light NCs.

Conclusions. Thus, prolonged hyperglycemia in SIDM in parvocellular nuclei of the hypothalamus causes neuronal death to a lesser extent due to apoptosis, and to a greater extentdue due to hydropic dystrophy and colliquative necrosis, especially in the long term of the experiment (on the $70^{\text {th }}$ day), and leads to the development of diabetic neuroendocrinopathy.

Key words: hypothalamus, arcuate nucleus, ventromedial nucleus, neuron, neuroendocrine cell, streptozotocin-induced diabetes mellitus.

\section{ВИРАЖЕНІСТЬ ПРОЦЕСІВ АПОПТОЗУ В ДРІБНОКЛІТИННИХ ЯДРАХ ГІПОТАЛАМУСА ПРИ СТРЕПТОЗОТОЦИНІНДУКОВАНОМУ ЦУКРОВОМУ ДІАБЕТІ}

\author{
Жураківська О. Я. ${ }^{1}$, Жердьова Н. М. ${ }^{2}$, Олійник Р. П. ${ }^{1}$, Побігун Н. Г. ${ }^{1}$, \\ Костіцька І. О. ${ }^{1}$ Жураківський В. М. ${ }^{1}$, Міськів В. А. ${ }^{1}$, Ткачук Ю. Л. ${ }^{1}$, \\ Антимис О. В. ${ }^{1}$, Саган Н. Т. ${ }^{1}$, Князевич-Чорна Т. В. ${ }^{1}$ \\ ${ }^{1}$ Івано-Франківський національний медичний університет, \\ м. Івано-Франківськ, Украӥна \\ ${ }^{2}$ Центр інноваційних медичних технологій НАН Украӥни, м. Київ, Украӥна \\ zhurakivska.o.ya@gmail.com
}

Захворювання на цукровий діабет завдае великої соціально-економічної шкоди, що визначаеться витратами на медичне обслуговування і соціальне забезпечення хворих у зв'язку з інвалідністю та втратою працездатності. Велику увагу дослідників зосереджено на вивченні ролі нейропептидів гіпоталамуса та їхньої участі в регуляції функції панкреатичних острівців. Зважаючи на вищевикладене, метою нашого дослідження було встановити особливості морфофункціональних змін у дугоподібному (ДЯ) і вентромедіальному (ВМЯ) ядрах гіпоталамуса при стрептозотоциніндукованому цукровому діабеті (СЦД) у щурів. Використали гістологічні, імуногістохімічні, електронномікроскопічні, біохімічні та статистичні методи дослідження.

Результати. У ДЯ і ВМЯ на ранніх стадіях розвитку СЦД (14 доба) відмічалися досить поліморфні зміни. У ДЯ збільшувалась площа нейронів і їх ядер зростала чисельна щільність темних фонкціонально більш активних нейронів, з'являлись двоядерцеві світлі нейроендокринні клітини (НК). У світлих і темних НК ДЯ спостерігалось достовірне збільшення об'ємної щільності нейросекреторних гранул в 2-4 рази порівняно з контролем, у ВМЯ - у 1,2-2 рази. Такі морфофункціональні зміни 
у дрібноклітинних ядрах гіпоталамуса та зростання об'ємної щільності нейросекреторних гранул в їхніх НК вказують на посилений синтез нейрогормонів, які безпосередньо впливають на аденогіпофріз та підвищення фонкціональної активності НК ДЯ і ВМЯ. На 70 добу СЦД у ВМЯ і ДЯ гіпоталамуса, відмічалось зменшення чисельної щільності нейронів за рахунок світлих НК, збільшувалась чисельна щільність вакуолізованих, темних пікноморфних і апоптичних нейронів. Апоптозний індекс в досліджуваних ядрах гіпоталамуса зростав у 2-4 рази, порівняно з контролем. При цьому площа профільного поля НК зростала, а ядер - зменшувалась, що приводило до зменшення ядерно-цитоплазматичного індекса та вказувало на зменшення їх функціональної активності і підтверджувалось зменшенням об'емної щільності нейросекреторних гранул в НК у 1,9-2,1 рази в ДЯ і в 2,7-4,7 рази у ВМЯ. На ультраструктурному рівні у світлих НК спостерігались виражені деструктивні процеси за типом вакуольної дистрофії, розвиток сателітозу та нейронофагії.

Висновок. Таким чином, тривала гіперглікемія при СЦД у дрібноклітинних ядрах гіпоталамуса викликає загибель нейронів меншою мірою, шляхом апоптозу і, більшою мірою, особливо у віддалених термінах експерименту (70 доба), за рахунок гідропічної дистрофії та колікваційного некрозу та призводить до розвитку діабетичної нейроендокринопатії.

К л ючові слов а: гіпоталамус, дугоподібне ядро, вентромедіальне ядро, нейрон, нейроендокринна клітина, стрептозотоциніндукований цукровий діабет. 